\title{
Pola Asuh Pendidikan Kerohanian Pada Anak
}

\author{
Mardiharto \\ Sekolah Tinggi Teologi Baptis Indonesia Semarang \\ pastormardi@gmail.com
}

\begin{abstract}
ABSTRAK
Anak-anak sangat perlu sekali mendapatkan pendidikan kerohanian sejak dini, hal ini yang sering kali terlewatkan oleh banyak orang tua untuk memberikannya. Karena banyak orang tua hanya berpikir untuk memberikan pendidikan kepada anak-anak di sekolah formal saja. Pendidikan kerohanian sangat perlu diberikan kepada anak-anak mulai sejak dini, dan dalam memberikan pendidikan tersebut ada banyak pola yang dapat digunakan dalam mengasuhnya. Dari sekian banyak itu diantaranya adalah dengan cara memberikan pengajaran yang terus menerus untuk diulang-ulang sampai anak dapat memahaminya. Dan juga dengan pola asuh pendisiplinan pada anak, karena tanpa pola pendisiplinan anak bisa menganggap pendidikan kerohanian tida perlu. Untuk itulah bahwa sangat penting sekali ada pola asuh yang diberikan kepada anak-anak dalam memberikan pendidikan kerohanian.
\end{abstract}

Kata kunci: Pola, Asuh, Pendidikan, Kerohanian, Anak

\section{PENDAHULUAN}

Keluarga adalah bagian dari setiap manusia, keluarga juga merupakan bagian dari kehidupan manusia. J.Keat Wiles dalam bukunya "Keluarga Pada Mulanya Hingga Dalam Tuhan" mengatakan: " Jikalau kita bermaksud untuk mengatakan atau memikirkan sesuatu yang pasti berkenaan dengan kehidupan seorang manusia, maka hal-hal yang menyangkut kehidupan keluargalah yang tepat". ${ }^{1}$ Keluarga juga bisa dikatakan sebagai kumunitas masyarakat terkecil. James E. Gardner mengatakan:

"Di dalam keluarga selalu ada komponen yang saling berhubungan satu dengan yang lain. Komponen itu terdiri dari ayah, ibu, dan anak. Hubungan dalam keluarga merupakan suatu hubungan segitiga yang tidak dapat dipisahkan satu dengan yang lain. Orang tua mempunyai peranan yang paling penting dalam keluarga yaitu untuk mewariskan nilai, memberikan harapan untuk masa depan, dan konsep dasar berkenaan dengan hidup."2

\footnotetext{
${ }^{1} \mathrm{~J}$ Keat Wiles, Keluarga Pada Mulanya Hingga Dalam Tuhan (Semarang, STBI 1986) V.
}

Melalui keluarga ini maka anak akan bisa belajar mengenai berbagai hal mengenai prilaku dan sifat-sifat kepribadian yang mendasar yang dapat dipergunakan untuk berhubungan dengan orang lain di sekitarnya. Disamping itu juga anak - anak akan bisa bertumbuh dengan baik dan merasa bangga bila nilai - nilai yang mendasar tentang hidup itu diperoleh dari orang tua mereka. Sebagai orang tua tentunya memiliki tanggung jawab yang sangat penting untuk mendidik, membimbing serta mengarahkan anak-anaknya supaya berhasil. Setiap orang tua memiliki kerinduan yang sama yaitu untuk dapat mendidik anak-anaknya sebaik mungkin dan juga dalam pendidikan rohani setiap orang tua juga berharap dapat memberikan pendidikan rohani yang cukup untuk menjadikan anaknya memiliki kehidupan yang benar di mata masyarakat, terlebih dihadapan Tuhan.

\section{METODE PENELITIAN}

Penulisan jurnal ini dengan menggunakan metode studi pustaka untuk mendapatkan datadata dan pembahasannya.

\footnotetext{
${ }^{2}$ James E. Gardner, Memahami Gejolak Masa Remaja, (Jakarta: Mitra tama,1989),173.
}

Mardiharto, Pola Asuh Pendidikan Kerohanian... 


\section{PEMBAHASAN}

Mendidik anak adalah suatu tanggung jawab orangtua yang tidak bisa diwakilkan kepada siapapun juga. Alex Sobur juga menegaskan mendidik anak adalah tugas yang mulia yang pernah diamanatkan Tuhan kepada para orang tua. Selain dari pada itu mendidik anak adalah memberi pengaruh dalam pembentukan pribadi anak dan watak yang akan dibawanya sampai dewasa nanti. ${ }^{3}$ Pembentukan pribadi dan kerohanian seorang anak tidak bisa terbentuk begitu saja akan tetapi memerlukan suatu pengaruh dari orang tua. Menurut Suhartin mendidik anak adalah membantu dengan sengaja pertumbuhan anak dalam mencapai kedewasaan. ${ }^{4}$

Dengan demikian pertumbuhan kedewasaan anak tidak terjadi dengan sendirinya melainkan orang tua dengan sengaja membantu dalam proses pendewasaan tersebut sehingga tujuan kedewasaan anak bisa tercapai. Karena orang tua menjadi yang terutama dalam mendidik anak maka diperlukan suatu gaya yang tepat dan efektif sehingga prilaku anak dapat sesuai dengan yang diharapkan setiap orang tua. Menurut Jhon W. Santrock gaya mendidik atau mengasuh anak bagi tiap orang tua memiliki empat jenis gaya diantaranya yaitu: gaya mendidik anak secara otoritarian, gaya mendidik anak secara otoritatif dan gaya mendidik anak dengan cara mengabaikan, gaya mendidik anak yang menuruti. ${ }^{5}$

\section{Pola Orang Tua Dalam Mendidik Kerohanian Anak}

Mendidik kerohanian anak adalah bagian yang sangat penting dalam kehidupan orang tua. Jhon C. Maxwell dalam bukunya Mengembangkan Talenta

\footnotetext{
${ }^{3}$ Alex Sobur, Pembinaan Anak dalam Keluarga, (Jakarta:BPK Gunung Mulia),1.

${ }^{4}$ Suhartin Citrobroto, Cara Mendidik Anak dalam

Keluarga Masa Kini, (Jakarta: Bhratara karya

Aksara), 4.

${ }^{5}$ Jhon W. Santrock, Perkembangan Anak (Jakarta:

Erlangga,2002), 167

${ }^{6}$ Jhon C. Maxwell, Mengembangkan Talenta

Kepemimpinan Anak Anda (Jakarta: Imanuel

2002), 10 .
}

Kepemimpinan Anak Anda mengutip peryataan Neal Postman yaitu: " anak-anak adalah pesan hidup yang kita utus pada masa yang tidak bisa kita lihat". 6 Ini berarti bahwa orang tua tidak bisa melepaskan begitu saja anak-anak untuk menjalani kehidupan di dunia ini. Oleh karena itu para orang tua dalam mendidik anak memerlukan prinsip-prinsip kebenaran firman Tuhan. Dalam sebuah penelitian yang dilakukan oleh George Barna dalam the Barna Research Group mengadakan studi mengenai orang-orang yang datang kepada Kristus. Dari penelitian itu menunjukan sebuah fakta penurunan orangorang yang menerima Kristus dari 32 persen menjadi empat persen. Dari penurunan tersebut diantaranya usia 13 dan 18 tahun. $^{7}$ Sangat jelas bahwa kehidupan kerohanian yang kuat perlu dimulai sejak dini. Melihat situasi demikian maka sebagai orang tua perlu mempersiapkan kerohanian anak-anaknya. Mendidik kerohanian anak sesuai dengan iman Kristen adalah hal yang sangat penting karena merupakan sebuah dasar dari pendidikan pendidikan yang lain. ${ }^{8}$ Marjoriel L. Thomson juga mengungkapkan bahwa Perjanjian Lama bagaimana bangsa Israel, selama berabad-abad memehami dirinyan sendiri dalam hubunganya dengan satu-satunya Allah besar. Indentitas Israel secara hakiki terikat pada perjalanan sejarahnya bersama dengan Allah, yaitu sejarah yang disampaikanya secara lisan dari generasi ke generasi dan diperingati dalam perayaanperayaan masyarakat dan peribadahan keluarga, dan untuk mengingat hal itu maka dikenalah tradisi tulisan. ${ }^{9}$

Penulis buku Tumbuh Kembang Anak Anne Neufeld Rupp, mengatakan, "dalam perjanjian baru telah mengindikasikan bahwa keluarga (orangtua: ayah dan ibu) berkewajiban dan bertanggung jawab juga mendidik anakanak mereka di dalam iman kepada Tuhan serta hidup yag sesuai dengan kehendak Tuhan. Jadi secara teologis mendidik anak dalam

\footnotetext{
${ }^{7}$ Connie Neumann, Pendewasaan Anak Dalam Rentang Lingkup keluarga (Bandung: PT. Visi Anugrah Indonesia), 131.

${ }^{8}$ Homringhausen,E.G dan I.H Enklaar. Pendidikan

Agama Kristen. (BPK Gunung Mulia 1996), 130.

${ }^{9}$ Marjoriel L. Thomson, keluarga Sebagai Pusat

Pembentukan ( Jakarta: BPK Gunung Mulia, 1999),97.
} 
pemahaman iman Kristen adalah suatu kewajiban dan tanggung jawab yang tidak boleh ditinggalkan. Anak adalah titipan dan juga karunia yang dipercayakan kepada manusia, maka untuk itu orang tua sebagai wakil Allah yang kelihatan di dunia ini harus bertanggung jawab mendidik, membimbingdan memelihara supaya anakanak mereka menjadi insan yang berbudi pekerti luhur, berbakti kepada Tuhan dan mengasihi sesamanya. ${ }^{10}$ Oleh karena itu maka para orang tua perlu mengunakan Gaya yang akan mendukung pertumbuhan kerohanian anaknya.

\section{Pengajaran Kerohanian Pada Anak}

Musa adalah orang yang telah dipilih oleh Allah yang menulis tentang 5 (lima) kitab yang disebut Pentateuk. Salah satu dari 5 kitab tersebut adalah kitab ulanngan. Tentang bagaimana memberikan pengajaran kepada anak-anak dalam kitab ulangan dibahas dengan jelas. Ulangan 6:7a mengatakan:'haruslah

engkau mengajarkannya berulang - ulang kepada anak-anakmu dan membicarakannya apabila engkau duduk di rumahmu, apabila engkau sedang dalam perjalanan, apabila engkau berbaring dan apabila engkau bangun". Metode "pengulangan" artinya metode seorang pengajar menyampaikan materi atau bahan pengajaran, bukan hanya sekali melainkan lebih(berulang kali) dengan tujuan agar murid atau anak dapat memahami dan mengerti terhadap isi pengajaran yang dipelajari. Anak kalimat yang ditulis:...haruslah engkau mengajarkanya berulang ulang...”(U1 6:7a) mengandung makna harafiah "meruncingkannya" atau "mempertajamkanya."11 Jadi dengan mengajarkan berulang-ulang akan semakin mempertajam pengertian terhadap firman Tuhan sehingga mengerti untuk dilakukan bukan hanya sekedar menghafalkan. Dengan pengajaran seperti itu maka Israel dituntut untuk mengeluarkan seluruh kemampuan yang ada agar firman Tuhan

\footnotetext{
${ }^{10}$ Anne Neufeld Rupp, Tumbuh Kembang anak ( Jakarta: BPK Gunung Mulia, 2009), 13.

${ }^{11}$ I.J Cairns, Tafsiran Alkitab-Kitab Ulangan PS.111. (Jakarta:BPK Gunung Mulia,1994) 133-134
}

dapat dihayati dan diteruskan dari generasi ke generasi. Melalui pengajaran, ada tiga hal penting mengenai pengajaran itu sendiri dalam memberikan pendidikan kerohanian pada anak. Yang pertama pribadi pengajar setiap orang tua perlu memiliki kematangan rohani. Hubungan intim dengan Tuhan sangat diperlukan karena orang tua adalah pemimpin di keluarga. Pengajaran bukan hanya menyampaikan materi tetapi melakukan pemindahan gaya kehidupan kepada orang lain. Yang kedua isi pengajaran. Mengasihi Allah dengan segenap hati, segenap jiwa, dan segenap kekuatan. Artinya sebelum orang tua memberikan pengajaran maka orang tua sudah melakukan isi pengajaran yang akan diajarkan. Mengasihi Allah berarti juga akan tercermin dalam mengasihi sesama. Mengasihi Allah juga berarti memiliki ketaatan dan kepatuhan dalam menjalankan setiap perintah serta menjadikan Alkitab sebagai pedoman hidup. Yang ketiga metode Pengajaran. Waktu dalam memberikan pengajaran kepada anak tidak bisa dilakukan hanya sekali atau dua kali. Metode atau cara yang dilakukan harus berulang-ulang. Telah disebutkan pada waktu duduk di rumah pada waktu dalam perjalanan, pada waktu berbaring, padawaktu bangun, adalah pengajaran yang dilakukan secara terusmenerus dan berkesinambungan, terencana, dimana saja dan kapan saja dalam setiap keadaan. $^{12}$

\section{Pendisiplinan Kerohanian Pada Anak}

Pendisiplinan berarti orang tua sebagai seorang pemimpin dalam keluarga dalam menerapkan disiplin bukan diartikan atau identik dengan memberikan hukuman melainkan memberikan tuntunan secara berkelanjutan atau terus menerus secara konsisten kepada anak. Penulis kitab Amsal memberikan pengertian kepada setiap orang mengenai pendisiplinan yang terdapat dalam Amsal 10:1 mengatakan: " Anak yang bijak mendatangkan sukacita kepada ayahnya, tetapi anak yang bebal adalah kedukaan bagi ibunya". Sukacita sebagai orang tua bukan melihat anaknya berkelimpahan secara materi saja namun memiliki anak yang bijak merupakan

\footnotetext{
${ }^{12}$ Di kutip dari Skripsi Sutinah, Pola Asuh Orang Tua Dalam Menghadapi Kenakalan RemajaDi GITJ Smuber rejo Kabupaten Pati, 23.
} 
kebahagiaan yang tidak ternilai. Anak yang bijak tidaklah terjadi secara tiba-tiba melainkan orang tua yang mempersiapkan dengan kedisiplinan. Mengapa orang tua perlu mendisiplin anak dan bagaimana cara orang tua dalam mendisiplin adalah pertanyaan yang sangat penting yang perlu untuk dijawab.

Yakob Tomatala mengenai disiplin adalah "...disini disiplin harus diartikan sebagai "mendidik untuk perbaikan yang lebih baik". Disini disiplin tidak diartikan sebagai hukuman untuk orang yang bersalah, tetapi didikan atau tuntunan untuk bermotivasi, bersikap dan berkinerja baik secara konsisten. ${ }^{13}$ Dari pengertian diatas berarti orang tua sebagai seorang pemimpin dalam keluarga dalam menerapkan disiplin bukan diartikan atau identik dengan memberikan hukuman melainkan memberikan tuntunan secara berkelanjutan atau terus menerus secara konsisten kepada anak. Mendisiplin anak menurut Larry Christenson adalah sebuah kenyataan yang harus dilihat oleh para orang tua Kristen secara jelas : Allah menuntut tanggung jawab dari saudara mengenai tata - tertip anak-anak saudara. Kalau saudara menertibkan dan membesarkan mereka sesuai dengan firman-Nya, maka Ia akan memberikan restu dan berkat-Nya. Kalau saudara gagal dalam melaksanakan, saudara akan membangkitkan murkanya. ${ }^{14}$ Pendapat Cristenson menekankan betapa pentingya orang tua untuk mendisiplin anak mereka. Karena dengan melakukan disiplin kepada anak-anak maka para orang tua sedang melaksanakan tanggung jawabnya kepada Allah. Namun sering kali yang terlihat adalah banyak sekali orang tua yang memiliki pendapat yang kurang tepat yaitu dengan mendisiplin anak maka akan menjahui orang tua sehingga hubungan anak dan orang tua menjadi ada jarak.

\section{KESIMPULAN}

Pola asuh dalam memberikan pendidikan kerohanian pada anak akan sangat menentukan pada hasil. Walaupun

\footnotetext{
${ }^{13}$ Yakob Tomatala, Kepemimpinan Yang Dinamis,(Jakarta:YT Leadership Fondation, 1997), 249.
}

Volume 15, Nomor 1, April 2019 setiap orang tua bisa berbeda-beda dalam memberikan pendidikan kerohanian pada anak, namun jangan sampai orang tua melalaikan tugasnya atau bahkan dianggap tidak penting dalam memberikan pendidikan kerohanian pada anak. Pola asuh yang diberikan bisa berupa sebuah pengajaran yang terus menerus diulangulang hingga sang anak sendiri dapat memahami. Juga bisa dengan memberikan pendisiplinan pada anak, namun bukan sebuah penghukuman dan memberikan pendidikan kerohanian anak. Semoga para orang tua tetap memiliki pola asuh yang baik dan benar dalam memberikan pendidikan kerohanian pada anakanak yang dicnitainya untuk kehidupan masa depannya.

\section{REKOMENDASI}

Para orang tua harus memberikan pendidika kerohanian pada anak-anak mereka. Pendidikan kerohanian harus diberikan kepada anak-anak sedini mungkin supaya dapat menjadi gaya hidup anak-anak, hingga mereka menjadi dewasa.

Pegajaran yang terus menerus kepada anak-anak semakin memudahkan anak untuk dapat terus selalu mengingatnya. Dan pendisiplinan juga perlu diberikan supaya pendidikan yang diberikan akan dapat menjadi lebih efektif dan sungguh-sungguh dijalankan oleh anak.

\section{DAFTAR PUSTAKA}

Cairns, I.J. Tafsiran Alkitab-Kitab Ulangan PS.1-11. Jakarta:BPK Gunung Mulia, 1994.

Citrobroto, Suhartin. Cara Mendidik Anak dalam Keluarga Masa Kini, Jakarta: Bhratara karya Aksara.

Chistenson, Larry. Keluarga Kristen. Semarang: Yayasan Persekutuan

Betania. 2002.

Gardner, James E.Memahami Gejolak Masa Remaja. Jakarta: Mitra Utama,1989.

Maxwell, Jhon C. Mengembangkan Talenta Kepemimpinan Anak Anda. Jakarta: Imanuel 2002.

\footnotetext{
${ }^{14}$ Larry Christenson, Keluarga Kristen(Semarang: Yayasan Persekutuan Betania), 84.
} 
Neumann, Connie.Pendewasaan Anak Dalam Rentang Lingkup keluarga. Bandung: PT. Visi Anugrah Indonesia. 2005

Rupp, Anne, Neufeld. Tumbuh Kembang anak. Jakarta: BPK Gunung Mulia, 2009

Sobur,Alex. Pembinaan Anak Dalam Keluarga. Jakarta:BPK Gunung Mulia.

Santrock, Jhon W. Perkembangan Anak. Jakarta: Erlangga.2002.

Sutinah, Skripsi. Pola Asuh Orang Tua Dalam Menghadapi Kenakalan RemajaDi GITJ Suberrejo Kabupaten Pati. 2011.

Thomson, Marjoriel, L. Keluarga Sebagai Pusat Pembentukan. Jakarta: BPK Gunung Mulia, 1999.

Tomatala,Yakob. Kepemimpinan Yang Dinamis. Jakarta:YT Leadership Fondation. 1997.

Wiles, J. Keat. Keluarga Pada Mulanya Hingga Dalam Tuhan. Semarang: STBI 1986. 